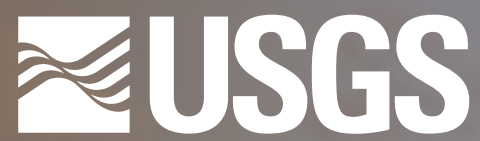

science for a changing world

USGS Water Observing Systems Program

Prepared in cooperation with the U.S. Army Corps of Engineers, Regional Sediment Management Program

\title{
Envisioning a Multi-Agency and Multi-Academic Institution Ceomorphology Data Exchange Portal
}

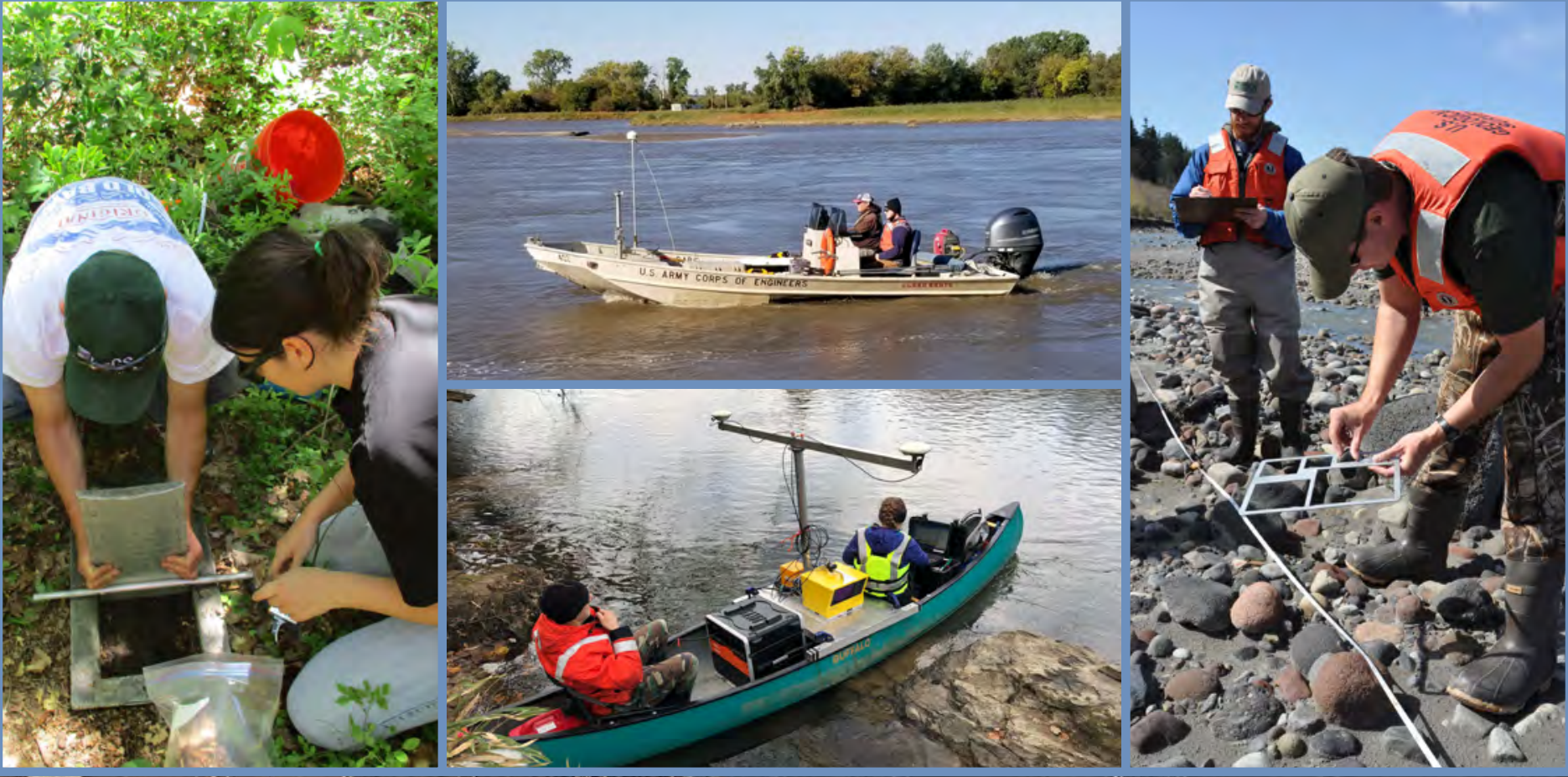

Open-File Report 2020 -1056

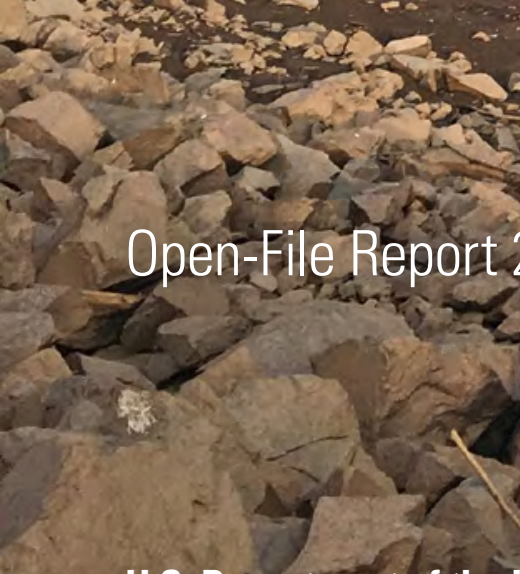

U.S. Department of the interior U.S. Geological Survey 


\section{Cover:}

Background image: Fall Creek Reservoir near Fall Creek, Oregon, during drawdown, showing sediment deposited in the reservoir. (photograph by Molly Wood, U.S. Geological Survey [USGS], November 7, 2018).

Center collage, clockwise from left: Sampling soil on a streambank at Smith Creek near Harrisonburg, Virginia (photograph by Allen Gellis, USGS, June 13, 2016); performing a bathymetric survey on the lower Missouri River (photograph by river and reservoir engineer, Omaha District, U.S. Army Corps of Engineers, May 20, 2020); conducting pebble counts on the North Fork Toutle River, Washington (photograph by Adam Mosbrucker, USGS, March 24, 2010); and conducting a terrestrial lidar survey of banks on the French Broad River near Bent Creek, North Carolina (photograph by Jeff Riley, USGS, November 15, 2019). 


\section{Envisioning a Multi-Agency and Multi-Academic Institution Geomorphology Data Exchange Portal}

By Molly S. Wood and Paul M. Boyd

USGS Water Observing Systems Program

Prepared in cooperation with the U.S. Army Corps of Engineers, Regional Sediment Management Program

Open-File Report 2020-1056 


\title{
U.S. Department of the Interior \\ DAVID BERNHARDT, Secretary
}

\author{
U.S. Geological Survey \\ James F. Reilly II, Director
}

U.S. Geological Survey, Reston, Virginia: 2020

For more information on the USGS - the Federal source for science about the Earth, its natural and living resources, natural hazards, and the environment—visit https://www.usgs.gov or call 1-888-ASK-USGS.

For an overview of USGS information products, including maps, imagery, and publications, visit https://store.usgs.gov/.

Any use of trade, firm, or product names is for descriptive purposes only and does not imply endorsement by the U.S. Government.

Although this information product, for the most part, is in the public domain, it also may contain copyrighted materials as noted in the text. Permission to reproduce copyrighted items must be secured from the copyright owner.

Suggested citation:

Wood, M.S., and Boyd, P.M., 2020, Envisioning a multi-agency and multi-academic institution geomorphology data exchange portal: U.S. Geological Survey Open-File Report 2020-1056, 19 p., https://doi.org/10.3133/ofr20201056.

ISSN 2331-1258 (online) 


\section{Contents}

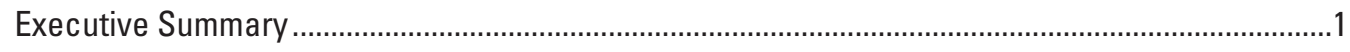

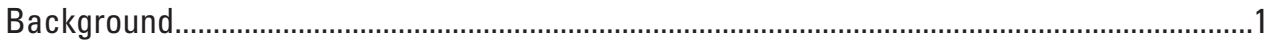

Working Group Participants....................................................................................................

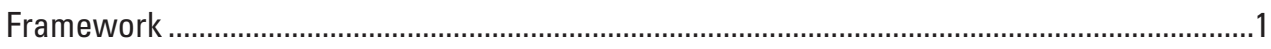

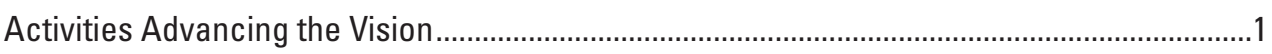

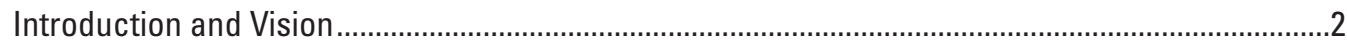

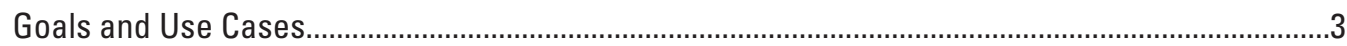

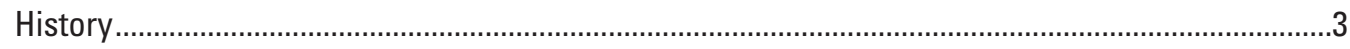

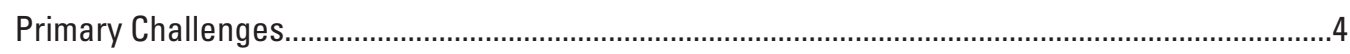

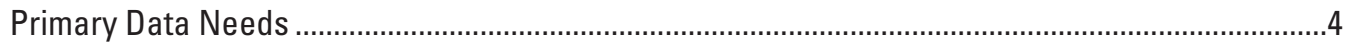

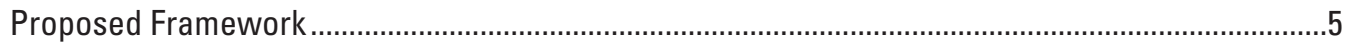

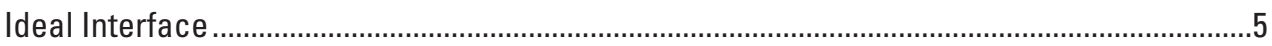

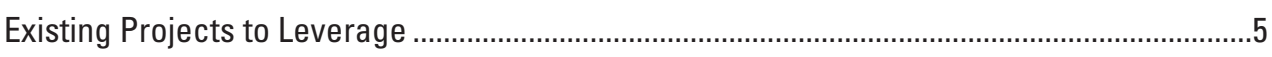

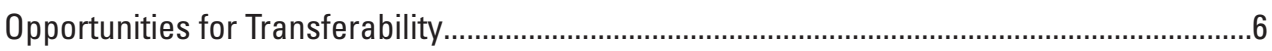

Project Activities in Fiscal Year 2019.....................................................................................

Early Fiscal Year 2019—Inter-Agency Meeting Presentations to USGS and USACE

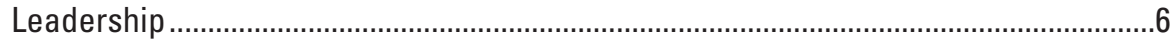

Mid-Fiscal Year 2019—Face-to-Face Meeting—Lakewood, Colorado, April 30-

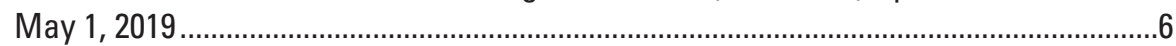

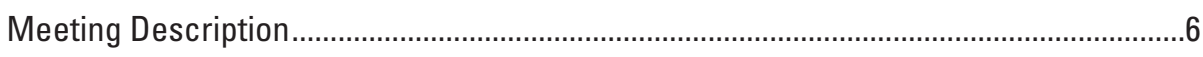

Meeting Organizers and Attendees..................................................................................

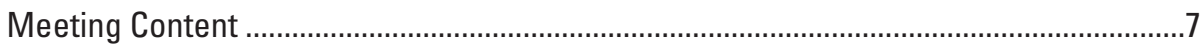

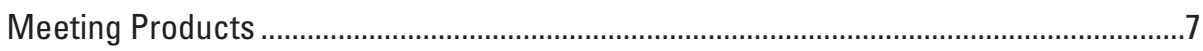

Late Fiscal Year 2019—Development of Fiscal Year 2020 Agency and Academic Institution Proposals .............................................................................................

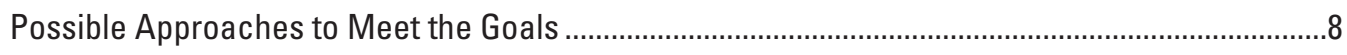

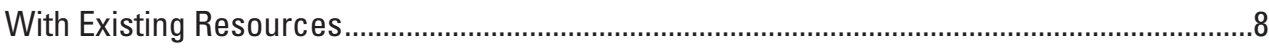

With Additional Resources .............................................................................................

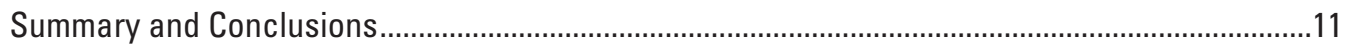

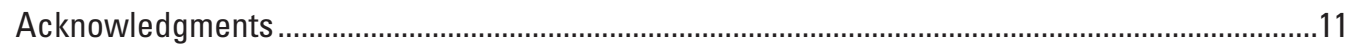

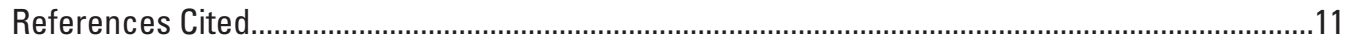

Appendix 12011 Working Group Meeting Agenda and Attendees.............................................13

Appendix 22019 Working Group Meeting Agenda and Attendees..............................................16 


\section{Figures}

1. Conceptual diagram of a possible Geomorphology Data Exchange Portal framework, which would allow data providers to upload geomorphology data by using standard web-based templates, provide attributes and metadata, and georeference data from river reaches and basins.

2. Screen capture of U.S. Army Corps of Engineers eHydro web-based bathymetric-data platform showing locations and numbers of bathymetric surveys conducted by USACE and its contractors in the Delaware River Basin and areas as far west as central Ohio.

3. Screen capture of U.S. Army Corps of Engineers Cross Section Viewer tool showing channel changes surveyed over several years within a single cross section on the Missouri River

\section{Abbreviations}

ACWI

ACWI SoS

ADCP

API

BLM

CIRES

CUAHSI

DRB

Esri

FY

GIS

HEC

IceSAT2

IWP

NASA

NGWOS

NHD

NIWR

NOAA

NWIS

NWS

ODNR
Advisory Committee on Water Information

Subcommittee on Sedimentation of the Advisory Committee on Water Information

Acoustic Doppler Current Profiler

application programming interface

Bureau of Land Management

University of Colorado Cooperative Institute for Research in Environmental Sciences

Consortium of Universities for the Advancement of Hydrologic Science

Delaware River Basin

Environmental Systems Research Institute

Fiscal Year

geographic information system

Hydrologic Engineering Center

Ice, Cloud, and Land Elevation Satellite-2

Integrated Water Prediction

National Aeronautics and Space Administration

Next Generation Water Observing System

National Hydrography Dataset

National Institute for Water Resources

National Oceanic and Atmospheric Administration

National Water Information System

National Weather Service

Ohio Department of Natural Resources 


\section{Abbreviations-Continued}

$\begin{array}{ll}\text { Reclamation } & \text { Bureau of Reclamation } \\ \text { RISE } & \text { Reclamation Information Sharing Environment } \\ \text { RSI } & \text { Reservoir Sedimentation Information } \\ \text { RSM } & \text { Regional Sediment Management } \\ \text { RWIS } & \text { Reclamation Water Information System } \\ \text { SLU } & \text { St. Louis University } \\ \text { STREAM } & \text { Spreadsheet Tools for River Evaluation, Assessment, and Monitoring } \\ \text { SWOT } & \text { Surface Water and Ocean Topography mission } \\ \text { 3DEP } & \text { Three-Dimensional Elevation Program } \\ \text { UI } & \text { University of lowa } \\ \text { USACE } & \text { U.S. Army Corps of Engineers } \\ \text { USDA ARS } & \text { U.S. Department of Agriculture Agricultural Research Service } \\ \text { USDA NRCS } & \text { U.S. Department of Agriculture Natural Resources Conservation Service } \\ \text { USFS } & \text { U.S. Forest Service } \\ \text { USGS } & \text { U.S. Geological Survey }\end{array}$


This page intentionally left blank. 


\title{
Envisioning a Multi-Agency and Multi-Academic Institution Geomorphology Data Exchange Portal
}

\author{
By Molly S. Wood ${ }^{1}$ and Paul M. Boyd²
}

\section{Executive Summary}

\section{Background}

Access to bathymetry and geomorphology data for rivers and reservoirs is a critical need in multiple agencies and academia. In 2011, the Subcommittee on Sedimentation of the Advisory Committee on Water Information (ACWI SoS) identified this need and initiated a multi-agency working group to identify the next steps needed at that time for the development of a geomorphology database. The conclusion of the 2011 working group was that a broad study was needed to examine data needs and existing databases and formulate the design specifications. Many of the agencies involved in the 2011 effort continue to collect and store bathymetry and geomorphology data in various formats and have developed disconnected tools for synthesizing and visualizing the data. These data are needed to make water-resource-management decisions regarding river restoration, resource protection, infrastructure design and sustainability, and flood-risk reduction, and during natural disasters. Sharing of data increases decision-making capacity by incorporating information from entire watersheds, provides knowledge from similar settings being managed or studied by other entities, and helps meet the goals of the Federal Open Water Data Initiative (https://acwi.gov/spatial/ owdi). Addressing these needs across broad spatial and temporal scales would be made more efficient if these data were available in consistent formats with standardized metadata and were either stored in one or more centralized databases or integrated with existing geospatial datasets. Because of renewed interest and technological advances, representatives from multiple Federal agencies and academic institutions have created a new working group to scope the development of a Geomorphology Data Exchange Portal (referred to as "the Portal" in this report) to increase access to needed data.

\section{Working Group Participants}

Agencies and academic institutions represented in the current (2019) working group include the U.S. Geological Survey (USGS), U.S. Army Corps of Engineers (USACE),
U.S. Department of Agriculture Agricultural Research Service (USDA ARS) and Natural Resources Conservation Service (USDA NRCS), Bureau of Reclamation (Reclamation), Bureau of Land Management (BLM), University of Colorado Cooperative Institute for Research in Environmental Sciences (CIRES), St. Louis University (SLU), University of Iowa (UI), and Consortium of Universities for the Advancement of Hydrologic Science (CUAHSI).

\section{Framework}

The ideal Portal would host geomorphology data from multiple sources in a centralized database or repository and would allow the user to access basic querying tools or build customized queries to download available data. Additionally, the Portal would allow others to build customized applications that seamlessly integrate field data entry in the database, crosswalks among datasets, and analyses and comparisons of datasets. In the short term, however, a realistic approach might be to develop a web-based framework that would show locations and types of available data but would direct users to external links for access to the data. The USGS, USACE, and their partners have developed similar portals and data-processing tools that could be leveraged. Another possible solution would be to integrate geomorphology data with existing national geospatial datasets, where feasible.

\section{Activities Advancing the Vision}

In Fiscal Year (FY) 2019, USGS and USACE project leaders presented elements of this vision to their agency leadership. An outcome of one of those presentations was the allocation of funding to organize a face-to-face meeting of the working group in Lakewood, Colorado during April 30May 1, 2019, to brainstorm approaches for developing the Portal. After the meeting, working group members submitted several proposals to obtain funding for various complementary efforts and developed a summary of the vision and a list of possible approaches.

${ }^{1}$ U.S. Geological Survey

2U.S. Army Corps of Engineers 


\section{Introduction and Vision}

River and reservoir bathymetry, sediment, and other types of geomorphology data are required to make water-resourcemanagement decisions regarding (1) river restoration, (2) resource protection, (3) infrastructure design and sustainability, (4) flood-risk reduction, and (5) natural-disaster planning and mitigation. The water-resources-management and scientific communities have expressed a need for free access to these types of data from a consolidated central source, with consistent hydrologic georeferences, formats, and definitions (Collins and others, 2012; Consortium of Universities for the Advancement of Hydrologic Science, 2018).

These needs could be addressed by developing a Geomorphology Data Exchange Portal (hereinafter referred to as "the Portal"), which ideally would consist of a centralized database with a web-based interface. If the Portal takes the form of a centralized database, it would allow users to upload georeferenced datasets with common metadata and dataquality standards, search for datasets of interest in a web-based map, and download datasets and associated metadata (fig. 1). The Portal would ideally provide a mechanism to publish and provide public access to previously unreleased datasets from multiple agencies and academic institutions. New datasets would be stored in a central repository or connected to existing databases through the Portal. Existing databases, portals, tools, and interfaces would be leveraged to avoid the need to build a completely new data architecture. Additionally, a complementary approach would be to integrate some types of geomorphology data with geospatial datasets such as the National Hydrography Dataset (NHD).

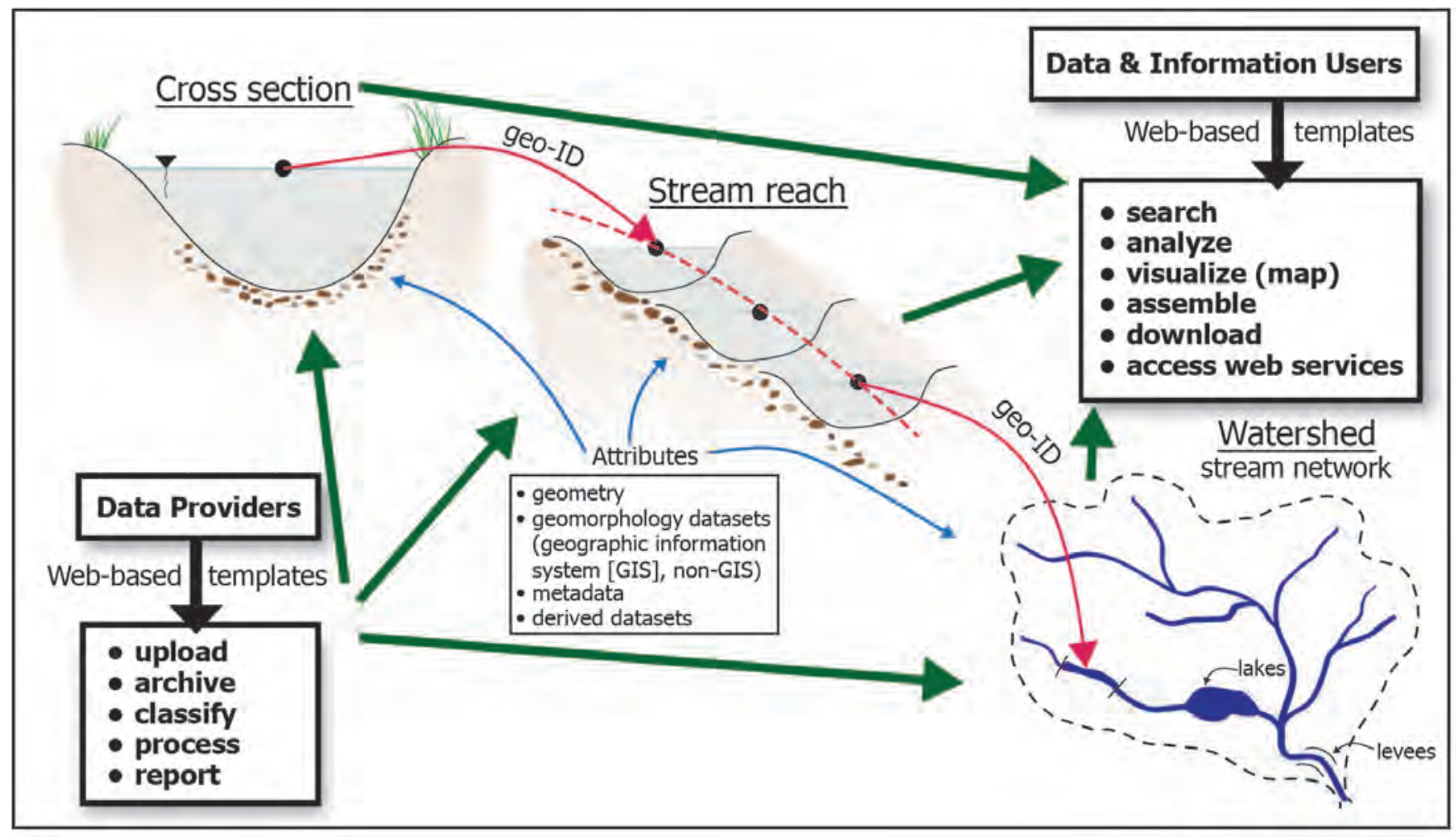

Figure 1. Possible Geomorphology Data Exchange Portal framework, which would allow data providers to upload geomorphology data by using standard web-based templates, provide attributes and metadata, and georeference data from river reaches and basins. Data and information users could then search for a location of interest and identify and download available data (Marian Muste, Professor, University of lowa and Consortium of Universities for the Advancement of Hydrologic Science, written commun., January 18, 2020). 


\section{Goals and Use Cases}

The overall goal of this effort is to provide connected data to advance geomorphic science and modeling while reducing the costs of data collection and the time required to gather and analyze datasets. How the goal is met will seem different to each user; however, any solution that meets this goal likely will be based on increasing access to large amounts of data that now are broadly dispersed. The following use cases highlight some examples of applications that could be helpful to end users of the Portal.

Natural Disaster Response. During floods, droughts, hurricanes, and wildfires, bathymetric and geomorphic data are vital for estimating river stages, storm-surge inundation, water availability, and debris-flow extents. In many cases, existing models can be used readily, but these models could be enhanced by using the most current in-stream data. Time often is limited for updates because management decisions must be made quickly, and the ability to rapidly query a database or portal for any new information increases the probability of accessing the newest available data and promotes a rapid response.

Planning Studies. Planners, engineers, and geographic information system (GIS) analysts extensively use bathymetry and sediment data while studying flood- and droughtrisk reduction, environmental mitigation, and civil-worksconstruction projects. Significant effort is expended in finding the available data, particularly historical data, which might already have been collected by multiple agencies or academic institutions in multiple states. On some smaller studies, technical analysis is limited by the financial commitment that data collection and discovery require. When data access requires less time and effort, the level of detail in analysis might increase.

River-Restoration and Geomorphic-Change Research. Design teams use bathymetry and geomorphology data to address environmental-compliance requirements for riverrestoration planning and design. The analysis generally includes evaluating the extent and magnitude of changes in river position and elevation over time to make predictions on how the landscape will respond to proposed actions, which may include restoring connections to floodplains, setting back or removing levees, widening bridges, replacing culverts, adding large woody debris for habitat, and (or) improving fish passage. The USGS initiated the use of the Vigil Network in the 1960s with the goals of having an international network of sites where basic geomorphic changes could be observed over long periods of time (Leopold, 1962; Emmett and Hadley, 1968). The Vigil Network includes 82 sites but has since been archived at https://archive.usgs.gov/archive/sites/ wwwpaztcn.wr.usgs.gov/vigil/. Having an updated Portal in which to store historical data for comparison over time is vital to (1) understand potential future trends of the river, (2) characterize reference reaches, and (3) properly assess proposed restoration actions.

Dam-Removal Analysis. Dams under consideration for removal often have been in place for a century or more. During this time, collection of geomorphic datasets may have been the responsibility of many different agencies and academic institutions. Previous dam-removal studies have expended significant effort in locating generations of datasets from multiple sources. A Portal that connects Federal, State, and local agencies and academic institutions directly to data sources used in dam-removal analyses (a step beyond links to publications available through existing, related portals) and that facilitates interagency coordination would have high usage as the number of dam-removal studies increases.

Sediment Budgeting and Sustainable Management. Management agencies take inventory of the effects of sedimentation on reservoir storage, river channels, navigationproject dredging, aquatic habitats, and water quality. As the footprint of sediment-budget analysis expands to cover entire watersheds, the number of geomorphic datasets increases, as does the number of dataset owners. At these scales, the Portal would have the additional benefit of enabling data sharing within large agencies that may have multiple offices collecting and storing data (for example, multiple USACE districts in a single watershed). Easy access to these large data repositories would enable the estimation of sediment budgets, integration of multiple data types for interdisciplinary studies, and development of strategies for sustainable sediment management over large temporal and spatial scales.

\section{History}

The Subcommittee on Sedimentation of the Advisory Committee on Water Information (ACWI SoS) initiated discussions on ways to improve sharing of geomorphology data through the formation of the National Stream Morphology Data Exchange working group in 2009. This working group drafted a list of desirable database attributes in 2010 and then organized a face-to-face meeting in Madison, Wisconsin, in 2011. An agenda and list of attendees at this 2011 meeting are provided in appendix 1, tables 1.1 and 1.2. As an outcome of the initial discussions at the meeting, working group members published an article entitled, "Developing a national stream morphology data exchange-Needs, challenges, and opportunities" (Collins and others, 2012). Agencies and academic institutions whose staff were at this meeting have submitted various proposals in recent years to obtain funding for the development of the Portal, although none were successful. The proposals include the following:

- 2012, National Institute for Water Resources (NIWR) Proposal;

- 2013, NIWR Proposal (resubmittal);

- 2014, National Aeronautics and Space Administration (NASA) Research Opportunities in Space and Earth Science Proposal; and

- 2016, USGS Powell Center Proposal. 
The Federal Geographic Data Committee and Advisory Committee on Water Information (ACWI) launched the Open Water Data Initiative (https://acwi.gov/spatial/owdi) in summer 2014, which pushed for integrating fragmented water information into a national framework open to the public and fueled additional discussions on the development of the Portal. In October 2018, lead managers and scientists from the USGS and USACE met to discuss opportunities for nationallevel collaborations between the two agencies. The concept of increasing access to river-channel bathymetry and geomorphic data piqued interest again, and both agencies agreed to fund their representatives to revive the discussions initiated by the ACWI SoS in 2009. USGS and USACE leaders recognized that the time had come for revisiting discussions because of new organizational alignments and priorities, including (1) complementary geospatial data and visualization projects, and (2) integrated water modeling and prediction tools. As a result, the USGS and USACE formed a new working group, not specifically affiliated with the ACWI SoS, to scope and brainstorm the development of the Portal.

\section{Primary Challenges}

Working group members have identified the following challenges with the current methods of accessing geomorphology datasets and with the development of the Portal:

- Significant volumes of historical data have not been preserved in any electronic format. They must be input to a database from paper or film media.

- The data available in digital form reside in multiple repositories and formats that are rarely accessible through platform-independent protocols.

- Not all agencies and academic institutions have their own databases dedicated to data storage. The databases that do exist tend to be agency-centric, project-specific, and limited in data types that can be accommodated.

- Developers of other multi-agency databases and portals (such as the Water Quality Portal, National Groundwater Monitoring Network, and Dam Removal Information Portal) have noted challenges with equalizing data quality, creating common data definitions, creating sustainable schema, and balancing agency participation and use with restrictions on data quality.

- In the USGS, most types of geomorphology data cannot be stored in the National Water Information System (NWIS), so they often are made available through the USGS trusted digital repository, ScienceBase. ScienceBase allows data access to only a single published product/location at a time, and the USGS must be the sponsor for any data release. After a data release is created in ScienceBase by the USGS, however, other
Federal agencies can contribute additional datasets in collaboration with the USGS. The current process is not ideal for open data sharing among multiple entities.

- Agreeing on standard terms, standard metadata, acceptable data quality, and spatial assignments of geomorphic features in a geospatial dataset will be challenging but must be addressed in any data-sharing platform.

\section{Primary Data Needs}

Merriam-Webster's Collegiate Dictionary (MerriamWebster, 2019) defines geomorphology as "a science that deals with the relief features of the earth and seeks an interpretation of them based on their origins and development." For the purposes of this application, we focus on the development of features that are directly tied to hydrologic influences. The term "geomorphology data" can encompass many different types of data, including but not limited to river-channel geometry, bathymetry, erosion/deposition rates, stratigraphy, hydraulic parameters, water surface and streambed slopes, riparian vegetation, and sediment characteristics. Common terms need to be defined for possible geomorphology data types. Based on a prioritization of use cases, the following types of data have been identified by the working group as critical to include and consider when building the Portal:

- River, reservoir, and lake bathymetry;

- Topography of river corridors and associated floodplains (channel centerlines, bank positions, anthropogenic features, and surface mapping);

- Water-surface elevations and reach slopes;

- Sediment properties - deposited, eroded, and transported (quantity, grain size, cohesiveness);

- Aerial imagery, historical maps, and site photographs taken over long time intervals;

- Channel roughness (for example, Manning's n) and its spatial variation in a reach;

- Land use/cover and riparian vegetation;

- Water-velocity profiles and vectors collected by acoustic Doppler current profilers (ADCPs) and other instrumentation; and

- Soil-erodibility metrics.

These data must be georeferenced to allow hydrologic association with relevant locations and accurately timetagged to be tracked (with changes recorded) over time. The richest datasets perhaps are those that are linked to USGS streamgages, making it possible to link geomorphic characteristics to hydrologic and hydraulic characteristics. 


\section{Proposed Framework}

\section{Ideal Interface}

The working group has discussed what would constitute the ideal Portal and interface. Three possible options have been discussed, although other options may become apparent during future discussions and data discovery:

- Dedicated Database. A full database hosted and owned by one agency or academic institution represented in the working group. The database would have a web-based interface and would allow upload and storage of data from multiple agencies and academic institutions. The uploaded data would have to meet minimum data-quality and metadata standards defined by the working group and host agency; however, the provider of the data would be responsible for the accuracy and quality of the data. A dedicated database would need to be submitted for certification as a trusted digital repository for data.

- Distributed Database. A web-based interface that would allow searching for locations of data in a map environment but then would direct the user to external sources of data hosted in external, agency- and academic institution-owned databases.

- Integrated Geospatial Database. Increased availability of data in national geospatial datasets (such as NHD/NHDPlus), to the extent possible. This option likely also would require development of a dedicated or distributed database to provide access to data types that are not easily imbedded in geospatial datasets (such as historical imagery).

These frameworks would be most useful if they allow users to process and visualize any uploaded or downloaded data. A modular infrastructure, to allow for users to build and share processing tools, should be considered during initial development. An ideal interface should allow a user to index and search for data based on georeferenced river networks. For example, a user ideally would be able to click on a point in a river or reservoir; and select an option to search upstream, downstream, both upstream and downstream, or define the extent (distance) of the search. The Portal then would return the data and associated metadata available within those search boundaries and would visually map the extent of the dataset. Working group members also acknowledge that some types of data may not be appropriate for public release because of cultural, national-security, or other concerns, so provisions for different access levels may be considered.

\section{Existing Projects to Leverage}

The USGS and USACE (among other agencies and academic institutions) have tools, resources, and new initiatives that could be leveraged if the Portal is developed. Some of the most logical leveraging opportunities include (web links are imbedded for brevity in this section):

- The USGS National Hydrologic Geospatial Fabric Project, particularly the River Corridors component. The USGS currently (2020) is planning this effort, which may include

- A set of integrated high-value geospatial-data themes made available with modern services linked to the Nation's hydrographic network;

- Modern, well-documented application programming interfaces (APIs) for accessing these data;

- Workflows and tools built around those APIs for accessing and manipulating information resources; and

- A pilot, or test, project in the Delaware River Basin related to providing centralized, hydrographically based access to river cross-section surveys (associated with the USGS Next Generation Water Observing Systems (NGWOS) program).

- The USGS Integrated Water Prediction Work Program (IWP), which will be designed to predict transport of sediment and other water-quality constituents, stream temperature, and other hydrologic parameters. IWP will integrate with the USGS's NGWOS program and be started in a pilot, or test, basin. Development of predictive modeling tools will depend on the types of data that could be provided through the proposed Portal.

- The USGS Three-Dimensional Elevation Program (3DEP), to build upon and have access to existing lidar-based elevation data for river corridors through the use of related tools.

- United States Interagency Elevation Inventory, a comprehensive nationwide listing of known high-accuracy topographic and bathymetric data for the United States and its territories.

- The USGS StreamStats, to possibly build upon the web-based architecture, web services, and GIS analytical tools already developed (although partnership at early stages may be difficult because of current backlogs). 
- The USGS NHDPlus Program (including NHDPlus High Resolution), which is a geospatial data suite that maps the national surface-water network and hydrologic-drainage areas. NHDPlus High Resolution allows linkages between landscapes and stream networks and mapping of stream networks at a higher resolution.

- The USACE eHydro, a web-based ArcGIS ${ }^{\mathrm{TM}}$ application that allows access to bathymetric-survey data.

- The USACE Reservoir Sedimentation Information (RSI) database, which compiles area-capacity data and metadata on the USACE and Bureau of Reclamation (Reclamation) catalog of water-storage reservoirs.

- The USACE Cross Section Viewer (Shelley and Bailey, 2018), a stand-alone software tool that can be used to store, display, and automate common geomorphic analyses with riverine cross-section data.

- The Reclamation Tessel system, a web-based GIS program that allows internal Reclamation users to view georeferenced data, including locations of and pathways for water diversions and areas estimated to become inundated if dams were to fail.

- The NASA Surface Water and Ocean Topography (SWOT) mission (to be launched in 2022) and Ice, Cloud, and Land Elevation Satellite-2 (IceSAT2) mission (currently operational).

- Existing "mappers" and data-access portals, including the USGS Flood Inundation Mapper, USGS Vigil Network Archive, Interagency Flood Risk Management Viewer, Short-Term Network Flood Event Viewer, Dam Removal Information Portal, National Ground-Water Monitoring Network Portal, USGS- and U.S. Environmental Protection Agencysponsored Water Quality Portal, the Consortium of Universities for the Advancement of Hydrologic Science (CUAHSI) HydroShare data-sharing application, USGS ScienceBase data catalog, the Bureau of Reclamation Information Sharing Environment (RISE), and the State of Vermont Stream Geomorphic Assessment Data Management System.

- Citizen science-based portals, such as the National Oceanic and Atmospheric Administration (NOAA) hosted International Hydrographic Organization Data Centre for Digital Bathymetry Viewer and the USGS and University of Buffalo CrowdHydrology database.

\section{Opportunities for Transferability}

The initial vision for the development of the Portal involved a pilot, or test, program with basic functionality for a basin of interest, with the understanding that the developed infrastructure and design should be transferable for implementation in other basins if funding is available for the expansion. Possible pilot basins discussed by the working group included the Delaware, Rio Grande, San Joaquin, Russian, Platte, Missouri, Columbia, Elwha, Upper Colorado, Willamette, Upper Mississippi, and Lower Mississippi Rivers, and Goodwin Creek. The ideal pilot basin would have dynamic sediment transport (various sediment types, sizes, and transport drivers) and would be rich in data from existing studies and monitoring programs (such as the USGS streamgage network).

\section{Project Activities in Fiscal Year 2019}

The current (2019) working group began efforts in Fiscal Year (FY) 2019 to discuss a new vision for the Portal and to determine next steps and necessary resources.

\section{Early Fiscal Year 2019-Inter-Agency Meeting Presentations to USGS and USACE Leadership}

Molly Wood (USGS) and Paul Boyd (USACE) presented elements of their vision to collaboratively develop the Portal to their agencies' leadership during two USGS/USACE Quarterly Inter-Agency Meetings held on October 4, 2018, and March 25, 2019. An outcome of the October meeting was that each agency agreed to contribute funding to support coordination of the working group face-to-face meeting that was held in spring 2019.

\section{Mid-Fiscal Year 2019_Face-to-Face Meeting- Lakewood, Colorado, April 30-May 1, 2019}

\section{Meeting Description}

This fairly high-level brainstorming meeting focused on the following steps needed to develop the Portal:

- Reviewing past efforts to scope and secure funding for the development of the Portal;

- Identifying basic data requirements and needs;

- Evaluating existing platforms, portals, and geospatial datasets that could be leveraged to provide an initial test or proof-of-concept for a pilot basin; and 
- Brainstorming resources and funding needed to develop the proof-of-concept pilot as well as a national program.

Additionally, this meeting built upon the discussions during the ACWI SoS-sponsored 2011 meeting in Madison, Wisconsin. A full agenda and list of attendees for the 2019 meeting are provided in appendix 2, tables 2.1 and 2.2.

\section{Meeting Organizers and Attendees}

The organizers of the meeting were Molly Wood (USGS), Paul Boyd (USACE), and Tim Randle (Reclamation). Additional logistical support was provided by Jennifer Bountry (Reclamation). The attendees included 22 representatives from Federal agencies and academic institutions with experience in collecting or analyzing geomorphology data and an interest in increasing access to these data for hydraulic and geomorphic analyses, modeling, and water-resource management.

\section{Meeting Content}

During the two days of the meeting, the attendees reported on projects, initiatives, or tools that had direct relevance to the Portal. These included stand-alone and web tools, databases, and data-workflow models. Throughout the presentations, the working group identified elements of existing or planned work that could be connected to meet the Portal goals.

After the presentations and discussion, the large group was split into four small groups. Each group had no more than two representatives from a single agency/academic institution to ensure a wide array of perspectives. The groups were asked to provide input on these questions:

- What types of geomorphic data are useful to you? List and rank.

- Who are the primary users of this data in your organizations?

- What is your ideal interface?

- What collection of features of the examples provided would meet your interface needs?

- Who should be charged with the quality assurance/ quality control and data management?

- Envision your unlimited-budget solution.

- Envision your zero-dollar solution.

- Do you have extensive watershed data that could be used in a pilot project?

The group reconvened to present their feedback and discuss the next steps. The meeting concluded with a discussion of suggested river basins, and how to apply what was learned to move forward and develop pilots for some of the interface features upon which all the participants had agreed as being necessary. The group also proposed the following ideas for naming the Portal:

- Stream Morphology Information Resource InterFace (SMIRF);

- Waterways Data and Geomorphology Exchange (WeDGE);

- River Assessment and Morphology Portal (RAMP);

- River Information Online (RIO); and

- Table of Hosted Lake, Waterway, and Estuarine Geomorphic data (THaLWEG).

\section{Meeting Products}

Products of the meeting included the following:

- A summary of meeting outcomes and next steps (this publication); and

- A list of ideas for increasing access to geomorphology data that could be accomplished with (1) existing resources (no additional funding, also known as the "zero-dollar solution"), and (2) additional resources (dedicated funding).

\section{Late Fiscal Year 2019-Development of Fiscal Year 2020 Agency and Academic Institution Proposals}

Working group members considered many of the ideas discussed during the face-to-face meeting in spring 2019 when developing several project proposals to accomplish elements of the vision:

- The USGS submitted a proposal to the USGS NGWOS Work Program for increasing access to and visualization of channel cross-section geometry collected as part of routine streamflow measurements at USGS streamgages in the Delaware River Basin (DRB). The project was funded in late FY 2019 to include purchasing of georeferencing equipment for ADCPs and training for USGS DRB staff on integration and use of the equipment. FY 2020 plans include collecting and processing of river cross-section measurements at select locations in the DRB and uploading and viewing the cross sections in an existing USACE tool to guide future development of visualization tools. This work would be done in collaboration with the USGS National Hydrologic Geospatial Fabric project. 
- USACE involvement in the effort is being supported by the Regional Sediment Management (RSM) Program (https://rsm.usace.army.mil) and the USACE Hydrology, Hydraulics, and Coastal Community of Practice. The USACE team was successful in receiving funding for a proposal to the RSM program for a seven-person team in FY 2020 titled "Exploring an Interagency Geomorphic Data Exchange PortalDeveloping Demonstrations of Data Storage and Sharing." The USACE team includes subject-matter experts in sediment transport, hydraulic modeling, river and reservoir engineering, and database and web development.

- Reclamation was successful in receiving funding for a proposal titled "Open Data Pilot for Integrating Bureau of Reclamation River and Reservoir topographic and sediment data into RISE." This is a FY 2020 effort to incorporate the Reclamation river and reservoir topographic and sediment data into RISE to address the Open Data Initiative and make the data more accessible both within and outside Reclamation. This project is intended to develop a data framework and flow that could be further developed into a pilot.

- An academic research team, led by the University of Iowa, submitted a proposal to and was successful in receiving funding from the National Science Foundation for a project titled "River Morphology Data and Analysis Tools (RiverMorph) —A Web Platform for Enabling River Morphology Research.” This project aims to develop a data platform and select tools to analyze and quantify geomorphic change.

Each of these proposals and projects would provide significant steps forward towards development of the Portal. The proposals might overlap one another, but at this stage in the development process, that overlap would not be inherently bad. A large, well-funded collaborative effort among several agencies is still in the future, and the results of these proposals could be used to identify the best methods that should be carried forward.

\section{Possible Approaches to Meet the Goals}

The working group has brainstormed some possible approaches to meeting the goals and vision described in sections, "Goals and Use Cases" and "Introduction and Vision," respectively. These approaches are divided into two categories: approaches that can be completed (1) with existing resources (under the assumption that no additional funding will be available), and (2) with additional resources (initially expected to be about $\$ 150,000$ shared by the USACE and USGS to start efforts). The described efforts are separate from, but will be complementary to, any work that may be completed if the activities described in section, "Late Fiscal Year 2019Development of Fiscal Year 2020 Agency and Academic Institution Proposals," proceed. Selected approaches likely will start with addressing new data and then will include historical data as time and funding allow.

\section{With Existing Resources}

Some agencies and academic institutions may be able to contribute existing resources to accomplish some steps toward the development of the Portal, including using staff time to engage in discussions with other collaborators involved in complementary programs and to develop initial data sharing websites. The working group discussed the following steps, which potentially could be accomplished using existing resources:

1. Discuss with the USGS ScienceBase team the possibility of allowing other Federal and academic partners to load and store data and the addition of a radio button to allow the filtering of results based on common geomorphic terms. At a minimum, the working group could start by developing a Geomorphology "Community" in ScienceBase to provide a central location for access to datasets and tools that include geomorphology elements.

2. Discuss leveraging opportunities with the Geospatial Research Laboratory and Remote Sensing/Geographic Information Systems Center of the USACE Engineering Research and Development Center.

3. Discuss leveraging opportunities with the CUAHSI HydroShare team.

4. Develop wiki-style pages through the USGS Community for Data Integration Confluence site for the working group to share resources, ideas, and links to known geomorphology datasets. This content could be added to an existing Earth-Science Themes Geomorphology Focus Group page (https://my.usgs.gov/confluence/display/cdi/ ETWG + Geomorphology+Focus + Group).

5. Align working group discussions and be represented at discussions with staff involved in the activities described in the section, "Existing Projects to Leverage".

\section{With Additional Resources}

Additional resources, possibly in the form of new funding and hiring of additional staff, would be needed to make substantial progress toward realizing the vision of the Portal. The working group discussed the following steps, which potentially could be accomplished if additional resources were available: 
1. Expand the USACE eHydro platform (fig. 2) to enable entry of data locations using simple, three-dimensional coordinates (xyz data) and additional attributes from multiple sources. May expand to show locations of and include links to sediment- and streamflow-monitoring stations operated by agencies other than USACE.

2. Expand the USACE Cross Section Viewer tool (Shelley and Bailey, 2018; fig. 3) and port to a web-based platform, perhaps integrated with eHydro. Allow data to be combined from multiple sources. Investigate the development of linkages between the USGS NWIS database and the Cross Section Viewer to access streamgage and measurement data and to allow computation of watersurface slopes for which common datums were used. Investigate the inclusion of some routines developed by the USGS Washington Water Science Center to evaluate river-channel changes on the basis of existing streamgage data and streamflow ratings.

3. Start efforts by expanding a web-based portal such as the Dam Removal Information Portal (https://www.sciencebase.gov/drip/) through the USGS ScienceBase data catalog, which points users to the locations of available data stored in various data- bases not controlled by the portal host. An existing portal would be enhanced to show locations of selected geomorphic data and would provide contact information and external links to available datasets.

4. Work with the USGS Web Informatics and Mapping group to expand the USGS Flood Inundation Mapper, Interagency Flood Risk Management Viewer, and (or) Short-Term Network/Flood Event Viewer applications to include access to river cross sections and bathymetric data, perhaps linked to nearby high water marks that were collected during different flows.

5. Investigate the development of a modular computational tool that would calculate and display sediment grain-size distribution plots and common grain-size metrics (such as the median and 90th-percentile diameters) at monitoring stations where detailed grain-size data are available from suspended, bedload, or bed-material sediment samples. The tool would be designed to integrate with existing tools or platforms (such as USGS NWIS or USACE eHydro, if expanded).

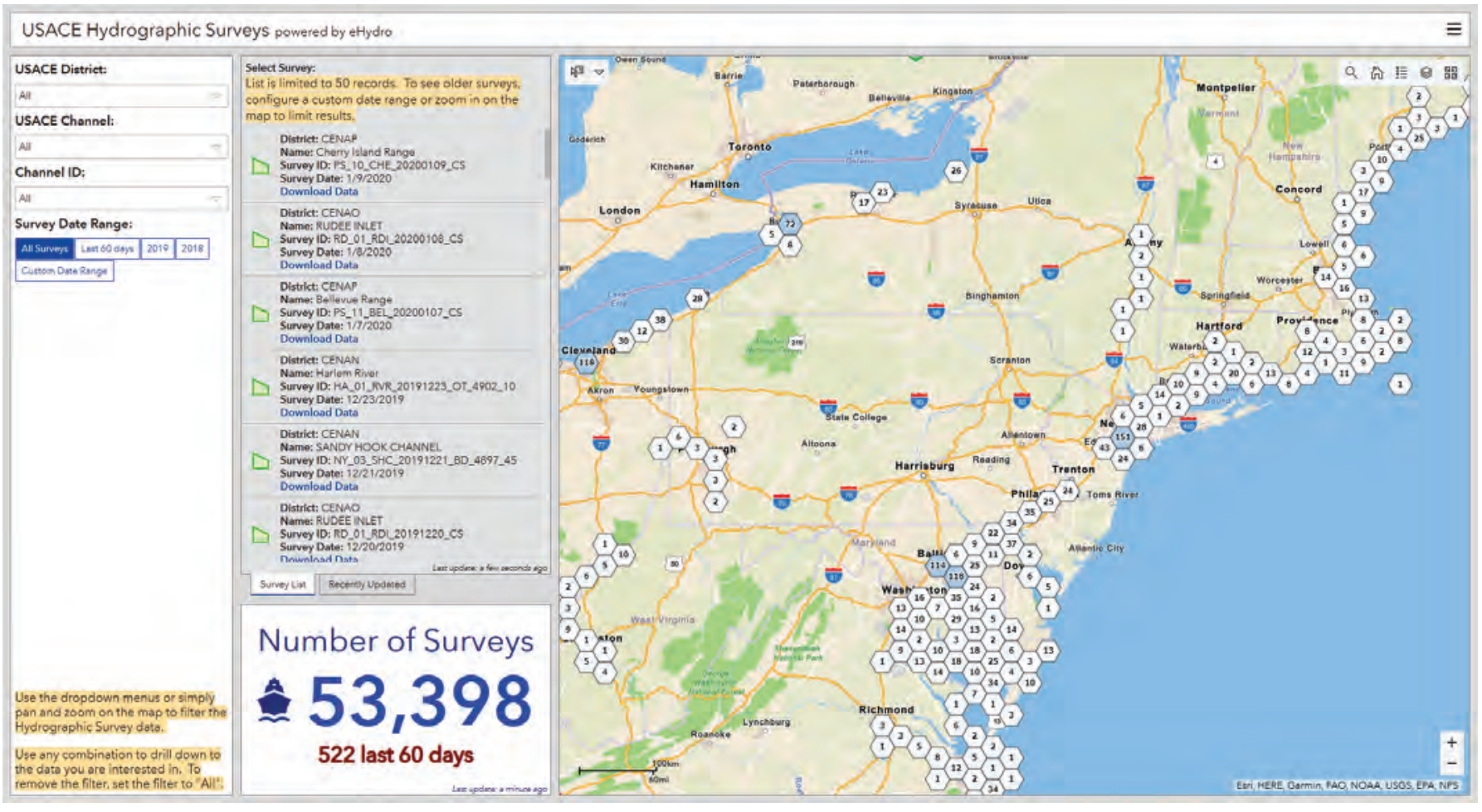

Figure 2. U.S. Army Corps of Engineers (USACE) eHydro web-based bathymetric-data platform showing locations and numbers of bathymetric surveys conducted by USACE and its contractors in the Delaware River Basin and areas as far west as central Ohio. A user can search for a location of interest and download available bathymetric-survey maps, georeferenced data, and metadata. 


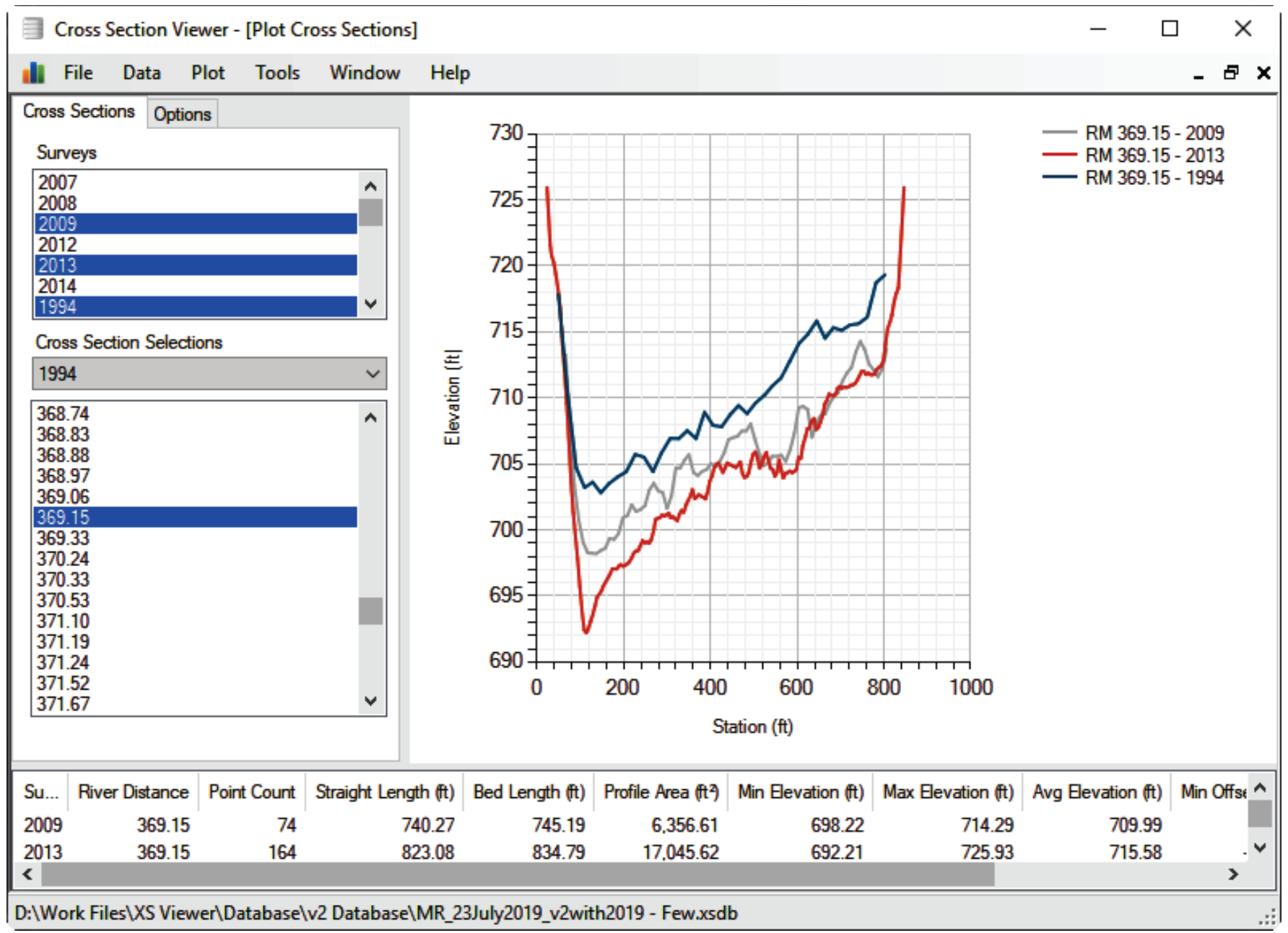

Figure 3. U.S. Army Corps of Engineers Cross Section Viewer tool showing channel changes surveyed over several years within a single cross section on the Missouri River.

6. Consult with the USGS Community for Data Integration to investigate the development of a modular tool to allow the development of time-lapse videos from the stitching together of repeated site photos, aerial imagery, or topography datasets for the visualization of changes over time in river corridors or site characteristics. The tool would be designed to integrate with existing tools or platforms.

7. Investigate the storage of georeferenced cross-section geometry and water-velocity measurements at USGS streamgages by using data from ADCPs in the USGS NWIS/Aquarius database. The data are collected but not always passed from the data-collection software to USGS field-note applications and subsequently to the USGS database. Storing these data in the USGS database might require development of new APIs, modifications to existing field software, and expanded database-storage capabilities.

8. Investigate linking geomorphic features with hydrologic characteristics at USGS long-term streamgages. Such a project might include documenting and improving access to geomorphic information collected during routine streamgaging visits, developing the relations between velocity and water level, and improving access to regional bankfull-streamflow curves (and associated data) through the USGS streamgage website.

9. Form a subgroup of the full working group to agree on and publish a common geomorphology data schema with consistent terms, units, and metadata standards. 


\section{Summary and Conclusions}

Geomorphology data can be broad in definition, including but not limited to river-channel geometry, bathymetry, erosion and deposition rates, stratigraphy, hydraulic parameters, water-surface and streambed slopes, riparian vegetation, and sediment characteristics. Open and consolidated access to geomorphology data collected by multiple entities would increase the quality and efficiency of water-resourcemanagement activities and research on river restoration, resource protection, infrastructure design and sustainability, flood-risk reduction, and natural-disaster mitigation. A working group has been formed with representatives from multiple Federal agencies and academic institutions to continue previous efforts to build a National Geomorphology Data Exchange Portal and to align any initiatives with new U.S. Geological Survey (USGS) and U.S. Army Corps of Engineers (USACE) program priorities. The working group met in Lakewood, Colorado, in spring 2019 to brainstorm approaches and next steps for increasing access to geomorphology data from existing and new resources. The working group considered three main options when brainstorming desirable elements of the Portal: (1) a dedicated, consolidated database and web-based data-access interface hosted by one entity; (2) a distributed database including a web-based interface showing the availability and locations of external sources of those data; and (3) an integrated geospatial database that would combine geomorphology data with existing national geospatial datasets. Several agency and academic proposals were developed after the spring 2019 meeting to request new resources to advance the vision of the Portal. Activities associated with successful proposals began in 2019 and will continue in 2020 and beyond. The working group will continue to correspond through email and, if funding allows, face-to-face meetings to determine which additional approaches identified in this report are most feasible. Additionally, USGS and USACE leads will continue to work with other staff involved in existing projects to advocate for additional funding to incorporate elements of the Portal in these projects.

\section{Acknowledgments}

The authors acknowledge senior leadership within the U.S. Geological Survey (USGS), Water Mission Area, and the U.S. Army Corps of Engineers (USACE), Regional Sediment Management Program, for supporting and providing guidance for this effort. The authors sincerely thank working-group participants in the following agencies and academic institutions who contributed to and reviewed this publication: USGS, USACE, U.S. Department of Agriculture/ Agricultural Research Service and Natural Resources Conservation Service, Bureau of Reclamation, Bureau of Land Management, University of Colorado Cooperative Institute for Research in Environmental Sciences, St. Louis University, University of Iowa, and Consortium of Universities for the Advancement of Hydrologic Science.

\section{References Cited}

Collins, M.J., Gray, J.R., Peppler, M.C., Fitzpatrick, F.A., and Schubauer-Berigan, J.P., 2012, Developing a national stream morphology data exchange-Needs, challenges, and opportunities: Eos-Transactions, American Geophysical Union, v. 93, no. 20, p. 195, accessed April 15, 2019, at https://doi.org/10.1029/2012EO200005.

Consortium of Universities for the Advancement of Hydrologic Science, 2018, A message from the Executive Director, in the CUAHSI September 2018 eNews newsletter: Consortium of Universities for the Advancement of Hydrologic Science, accessed April 1, 2019, at https://us3.campaign-archive.com/?u= aad7e9257f329c1a46ebbd412\&id=1 fccdec707.

Emmett, W.W., and Hadley, R.F., 1968, The Vigil NetworkPreservation and access of data: U.S. Geological Survey Circular 460-C, 21 p., accessed August 22, 2019, at https://pubs.usgs.gov/circ/1968/0460c/report.pdf.

Leopold, L.B., 1962, The Vigil Network: International Association of Scientific Hydrology-Bulletin, v. 7, no. 2, p. 5-9, accessed August 22, 2019, at https://doi.org/10.1080/ 02626666209493250.

Merriam-Webster, 2019, Merriam-Webster collegiate dictionary, accessed September 19, 2019, at https://www.merriamwebster.com/.

Shelley, J., and Bailey, P., 2018, The cross section viewer tool-A tool for automating geomorphic analysis using riverine cross-section data: U.S. Army Corps of Engineers, Engineer Research and Development Center Technical Note RSM-18-3, 9 p., accessed March 23, 2019, at https://dx.doi.org/10.21079/11681/26284. 
This page intentionally left blank. 


\section{Appendix 1. 2011 Working Group Meeting Agenda and Attendees}

Table 1.1. 2011 working group meeting agenda.

[Abbreviations: USGS, U.S. Geological Survey; ACWI SoS, Subcommittee on Sedimentation of the Advisory Committee on Water Information; USDA-ARS, U.S. Department of Agriculture Agricultural Research Service; NOAA, National Oceanic and Atmospheric Administration; USFS, U.S. Forest Service; ESRI, Environmental Systems Research Institute; ODNR, Ohio Department of Natural Resources; STREAM, Spreadsheet Tools for River Evaluation, Assessment, and Monitoring; CUAHSI, Consortium of Universities for the Advancement of Hydrologic Science; UI, University of Iowa]

\begin{tabular}{|c|c|c|}
\hline TIME & ACTIVITY & LEAD \\
\hline \multicolumn{3}{|c|}{ Wednesday, April 27, 2011} \\
\hline $7: 30-8: 00$ & Speakers load presentations & \\
\hline $8: 10-8: 15$ & $\begin{array}{l}\text { Brief background on the river-morphology database concept and ACWI SoS } \\
\text { connection }\end{array}$ & John Gray, USGS \\
\hline $8: 15-8: 25$ & $\begin{array}{l}\text { Overview on the need and timeliness of a stream- morphology database, work- } \\
\text { shop goals and products }\end{array}$ & Matt Collins, NOAA \\
\hline 9:20-9:40 & Water-quality common-data elements & Dan Sullivan, USGS \\
\hline $9: 40-10: 00$ & ODNR STREAM modules & $\begin{array}{l}\text { Dan Mecklenburg, } \\
\text { ODNR }\end{array}$ \\
\hline $10: 00-10: 15$ & Break & \\
\hline $10: 15-\mathrm{I} 0: 35$ & USGS Biological Database, habitat component & Pete Ruhl, USGS \\
\hline $10: 35-10: 55$ & Connections between river-morphology data and ESRI Arc Hydro & $\begin{array}{l}\text { David Maidment, CU- } \\
\text { AHSI }\end{array}$ \\
\hline 10:55-11:15 & Perspectives from the Center of Integrated Data Analytics & Nate Booth, USGS \\
\hline $11: 15-11: 35$ & Data models for multidimensional representation of river processes & Marian Muste, UI \\
\hline
\end{tabular}


Table 1.1. 2011 working group meeting agenda_Continued.

\begin{tabular}{|c|c|}
\hline \multicolumn{2}{|r|}{ Thursday, April 28, 2011} \\
\hline 8:00-10:00 & 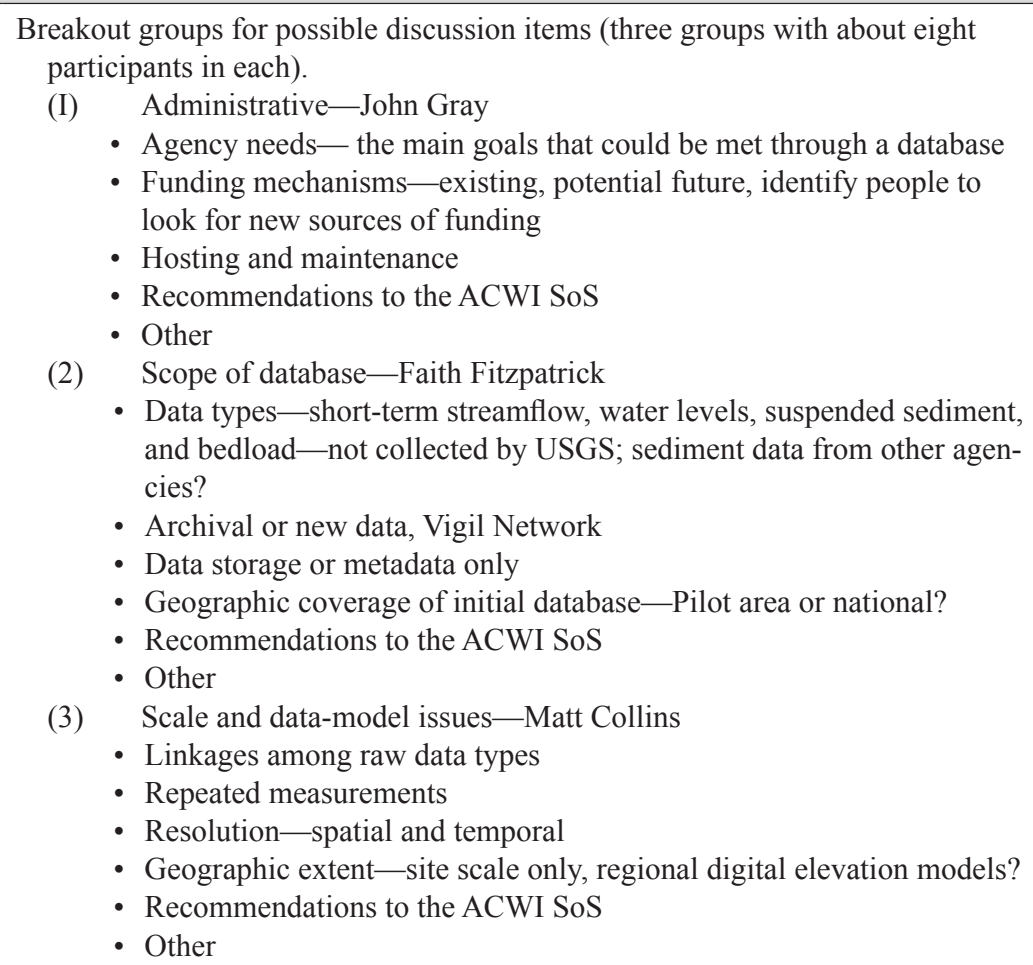 \\
\hline $10: 15-11: 55$ & Report out from breakout groups, synthesis, decision, next steps, wrap-up \\
\hline $12: 00$ & Adjourn \\
\hline
\end{tabular}


Table 1.2. List of 2011 working group meeting attendees.

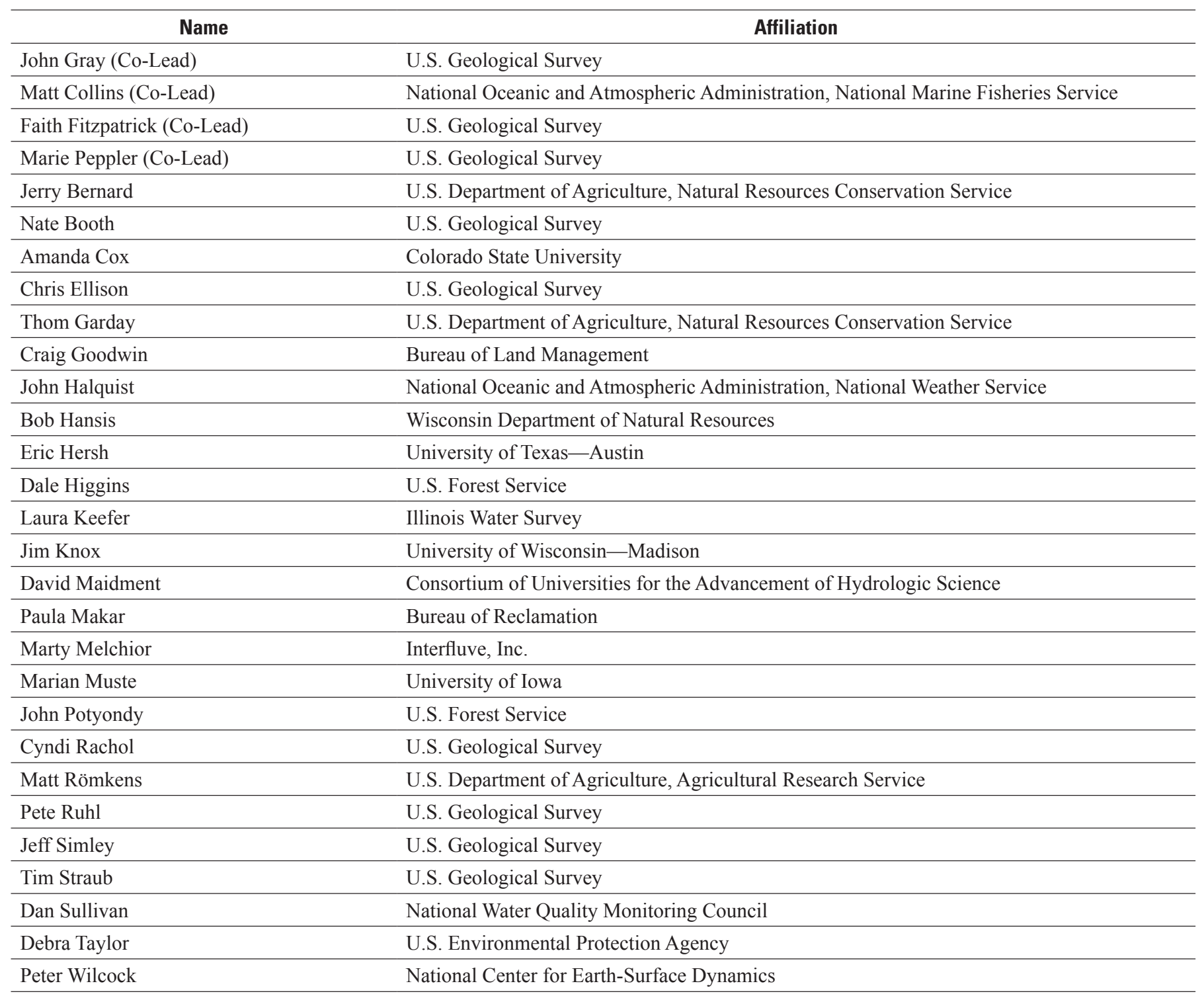




\section{Appendix 2. 2019 Working Group Meeting Agenda and Attendees}

Table 2.1. 2019 working group meeting agenda.

[Abbreviations: MDT, Mountain Daylight Time; USGS, U.S. Geological Survey; USACE, U.S. Army Corps of Engineers; Reclamation, Bureau of Reclamation; USDA-ARS, U.S. Department of Agriculture Agricultural Research Service; RSM, USACE Regional Sediment Management Program; HEC, USACE Hydrologic Engineering Center; RSI, USACE Reservoir Sediment Information database; NHD, USGS National Hydrography Dataset; 3DEP, USGS 3-Dimensional Elevation Program; IWP, USGS Integrated Water Prediction Program; RWIS, Reclamation Water Information System; BLM, Bureau of Land Management; NASA, National Aeronautics and Space Administration; SWOT, NASA Surface Water and Ocean Topography mission; CUAHSI, Consortium of Universities for the Advancement of Hydrologic Science; CIRES, Cooperative Institute for Research in Environmental Sciences]

\begin{tabular}{|c|c|c|}
\hline TIME (MDT) & ACTIVITY & LEAD \\
\hline \multicolumn{3}{|c|}{ Monday, April 29, 2019} \\
\hline \multicolumn{3}{|c|}{ Travel for all out-of-town attendees } \\
\hline $8: 00-8: 30$ & Welcome, review agenda, introductions & $\begin{array}{c}\text { Molly Wood (USGS), } \\
\text { Paul Boyd (US- } \\
\text { ACE), Tim Randle } \\
\text { (Reclamation) }\end{array}$ \\
\hline $8: 30-9: 00$ & $\begin{array}{l}\text { Overview of the concept of a Geomorphology Data Exchange Portal } \\
\text { - What are we trying to do? } \\
\text { - Why is it important? } \\
\text { - Past efforts } \\
\text { - Initial vision }\end{array}$ & $\begin{array}{l}\text { Molly Wood (USGS), } \\
\text { Paul Boyd (USACE), } \\
\text { Eddy Langendoen } \\
\text { (USDA ARS) }\end{array}$ \\
\hline $9: 30-9: 45$ & BREAK & \\
\hline $9: 45-11: 30$ & $\begin{array}{l}\text { Agency/academic institution presentations to touch on: } \\
\text { - Primary needs and uses for geomorphic data } \\
\text { - Existing and related efforts } \\
\text { - Existing platforms that could potentially be leveraged } \\
\text { - Candidate pilot basins with extensive geomorphic data } \\
\text { Session 1: USACE perspectives } \\
15 \text { minutes each (with some buffer): } \\
\text { - USACE-Overview of USACE efforts and common types of geomorphic } \\
\text { data collected by USACE (Paul Boyd) } \\
\text { - USACE-RSM activities and needs (Brandon Boyd, David May) } \\
\text { - USACE-Cross-Section Viewer (John Shelley) } \\
\text { - USACE-HEC database (Travis Dahl) } \\
\text { - USACE- EHydro portal (Gerald Thornberry) } \\
\text { - USACE-RSI experiences, lessons learned (Paul Boyd for Kate White } \\
\text { and Sean Smith) }\end{array}$ & Attendees \\
\hline $11: 30-13: 00$ & LUNCH & \\
\hline $13: 00-14: 15$ & $\begin{array}{l}\text { Continued agency/academic institution presentations- } \\
\text { Session 2: USGS perspectives } \\
15 \text { minutes each: } \\
\text { - USGS - Common types of geomorphic data and geomorphic analyses by } \\
\text { USGS (Faith Fitzpatrick, Adam Benthem) } \\
\text { - USGS-National Geospatial Program/NHD/NHDPlus, 3DEP, lidar por- } \\
\text { tals (Silvia Terziotti) } \\
\text { - USGS-IWP efforts and needs (Paul Kinzel, Molly Wood, Adam } \\
\text { Benthem) } \\
\text { - USGS-National Hydrologic Geospatial Fabric project (Roland Viger, } \\
\text { Pete McCarthy) } \\
\text { - USGS-StreamStats program and platform (Pete McCarthy) } \\
\text { - USGS-Multiagency data portals and lessons learned (Molly Wood) }\end{array}$ & Attendees \\
\hline
\end{tabular}


Table 2.1. 2019 working group meeting agenda-Continued.

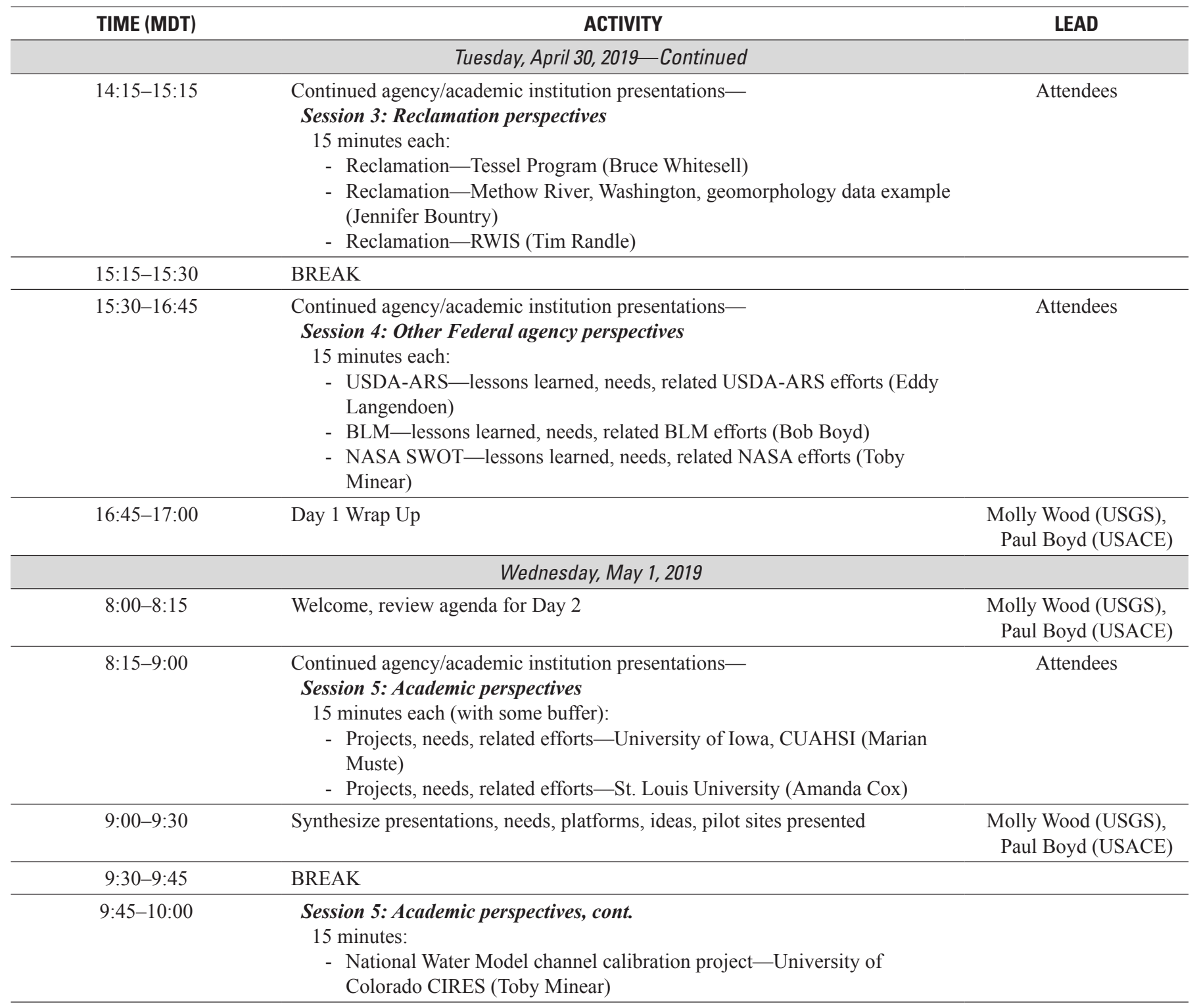


Table 2.1. 2019 working group meeting agenda_Continued.

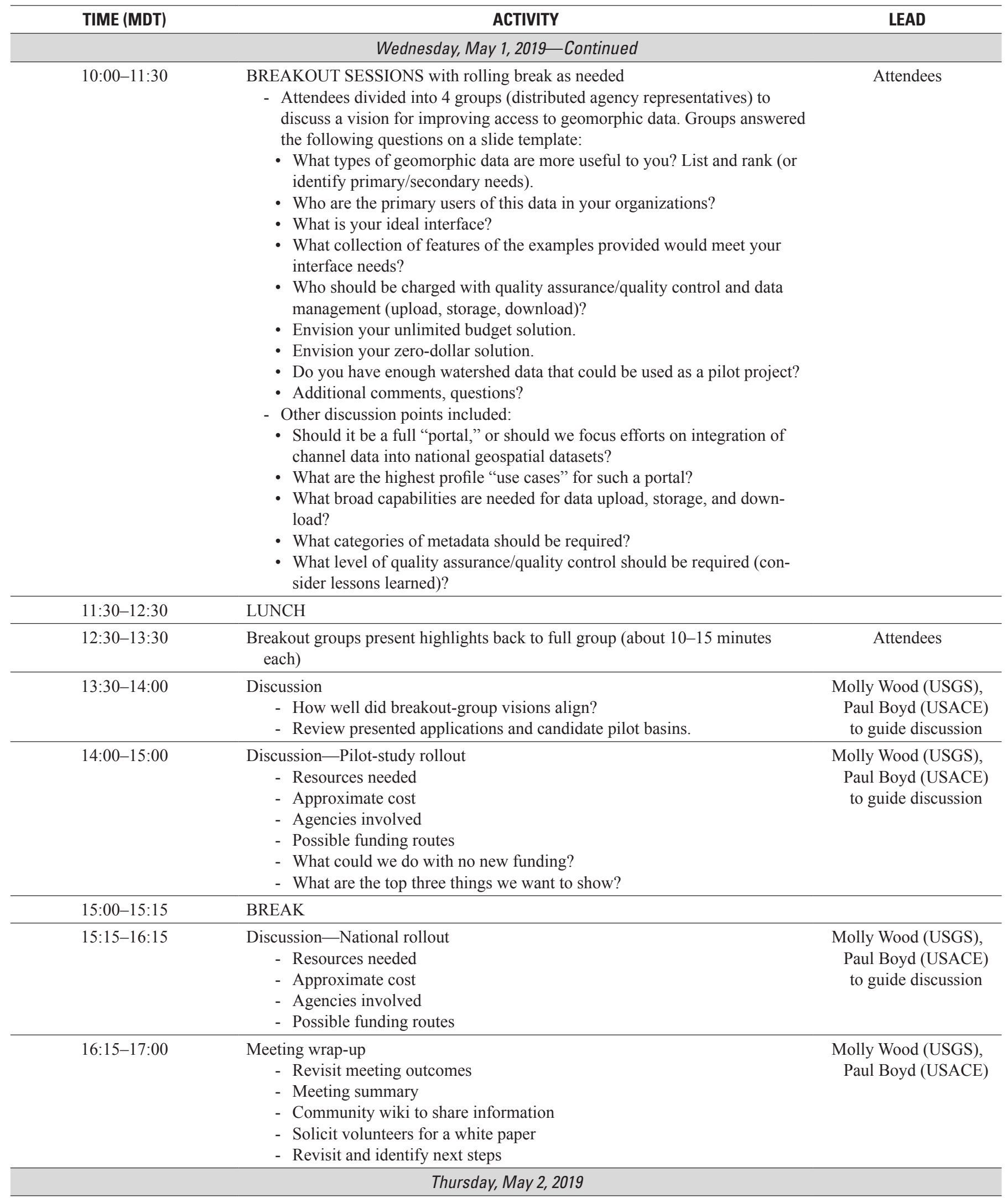


Table 2.2. List of 2019 working group meeting attendees.

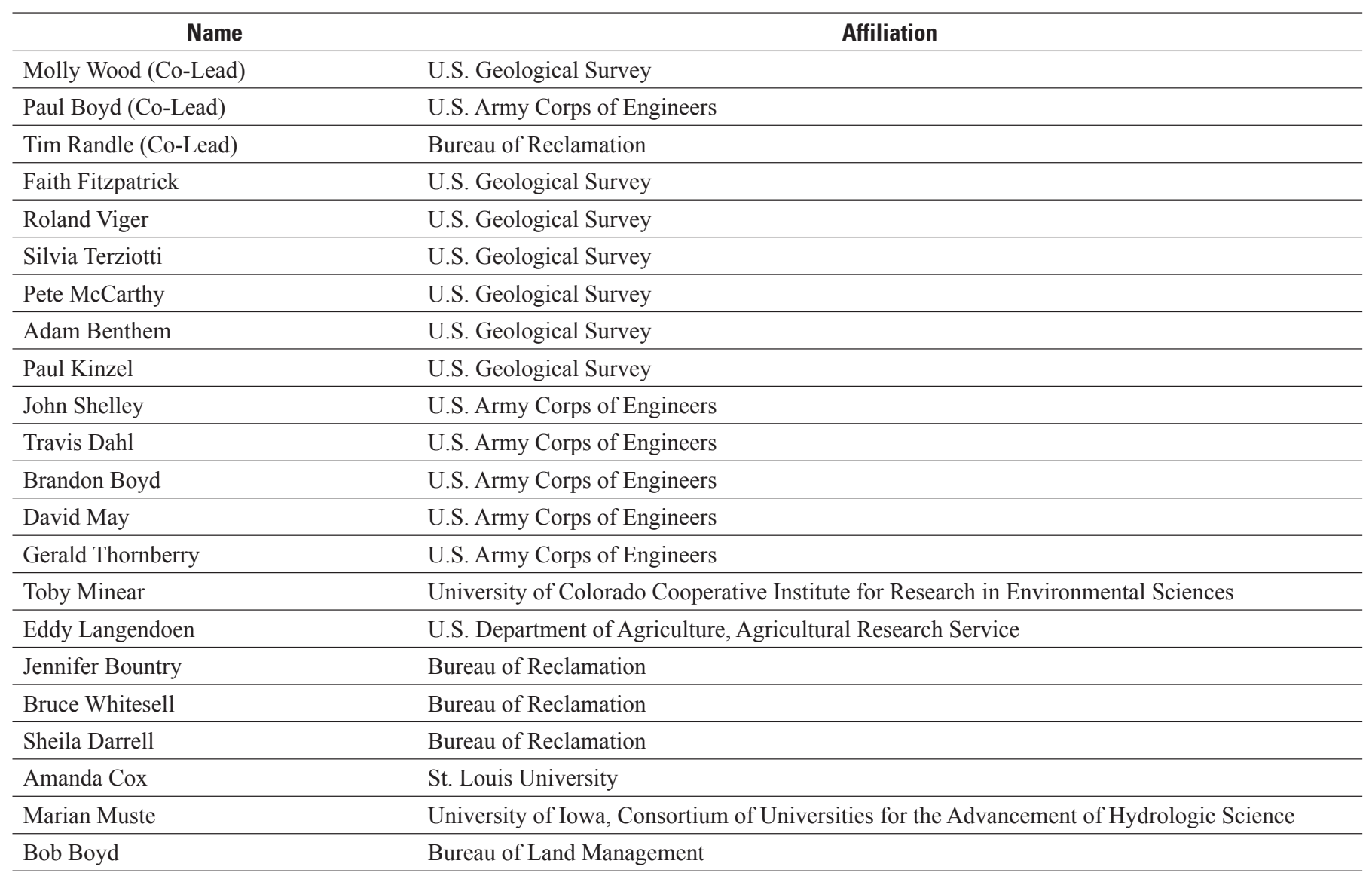

Invited but did not attend: U.S. Department of Agriculture, Natural Resources Conservation Service; National Oceanic and Atmospheric Administration; National Water Model Group in the National Center for Atmospheric Research. 

Publishing support provided by the U.S. Geological Survey Science Publishing Network, Tacoma Publishing Service Center

For more information concerning the research in this report, contact the Office of Associate Director, Water

U.S. Geological Survey

12201 Sunrise Valley Drive

Reston, VA 20192

https://www.usgs.gov/mission-areas/water-resources 
